\title{
The Role of Social Capital of Riau Women Farmer Groups in Building Collective Action for Tropical Peatland Restoration
}

\author{
Ashaluddin Jalil ${ }^{1}$, Yesi Yesi ${ }^{1}$, Seger Sugiyanto ${ }^{1}$, Dyah Puspitaloka ${ }^{2, *}$ and Herry Purnomo ${ }^{2,3}$ \\ 1 Sociology Department, Social and Politic Faculty, Riau University, Riau, Indonesia \\ 2 Center for International Forestry Research (CIFOR), Bogor, Indonesia \\ 3 IPB University, Bogor, Indonesia \\ * Correspondence author: d.puspitaloka@cgiar.org; Tel.: +62-251-8622622
}

\begin{abstract}
Collective action is important when the activities and costs of restoration cannot all be internalized by the government or when urgent maintenance is required beyond the scope of the restoration project. Collective action can be influenced by social capital. In this study, we examine components of social capital and the factors that affect them. Using key informant interview, household survey, and participant observation, we also identify the extent to which social capital is related to collective action. We found that women farmer groups have high social capital, which has led to strong collective action. Social capital in Dompas' women groups is characterized by the norms of trust and reciprocity. Strong trust and reciprocity are driven by shared culture and values and supported by kinship. Social capital arises from and is reflected in the interactions between individuals in the group. It is naturally embedded within the community, supported by strong motivation and commitment, primarily to improve the family welfare. The social capital established influenced and drove collective action, which contributes to successful management of the women farmer groups' action arena. This paper highlights the evidence of social capital and its relation to collective action in a case from restoration in the Global South. We suggest that for a restoration action to successfully mobilize voluntary, active participation from the community, the intervention should be designed with an emphasis on establishing social capital.
\end{abstract}

Keywords: social capital; women; peatland restoration; fire prevention; community-based; collective action

\section{Introduction}

Fire prevention and peatland restoration are critical to the Government of Indonesia's agenda. They are linked to Indonesia's nationally determined contribution (NDC) (Government of Indonesia, 2016) and other global pledges to reduce greenhouse gas emissions. Tropical peatland contains a significant amount of carbon (Joosten \& Couwenberg, 2008) and is key to achieving Indonesia's NDC and other climate targets. However, in 2015, progress toward this was threatened by severe forest and land fires, which caused massive greenhouse gas emissions (Field et al., 2016). Environmental, economic, tourism, and education losses amounted to USD 16.1 billion (Glauber et al. 2016). The fire mostly occurred in dry and degraded peatland, driven by socioeconomic and political factors, in addition to climatic conditions (Purnomo et al., 2017, 2019). Indonesia's tropical peatland had been subject to anthropogenic activities (Dommain et al., 2016; Hergoualc'h et al., 2017), increasing the likelihood of peat fires, especially during the long drought seasons. Recognizing the drivers and impacts of fire, the government established a 'zero burning' regulation and program (i.e., fire was prohibited in land preparation. It also strengthened law enforcement to prevent forest and land fires. In addition, the government established the Peatland Restoration Agency to facilitate the restoration of 2.26 million ha of peatlands through Presidential Decree No. 1/2016.

The successful restoration of peatlands is uncertain due to socioeconomic pressures and their ecological complexity. Hence, many peatland restoration projects combine socioeconomic and ecological approaches to achieve their goal (Puspitaloka et al., 2020). Often, restoration projects 
employ the 3Rs approach, rewetting, revegetation or replanting, and revitalization of the local community's livelihood. However, these approaches can be costly. It has been estimated that the lowest costs of restoration are an average of USD 1,866/ha (Hansson \& Dargusch, 2017). It is very likely that the actual costs will be higher than this due to the urgency of addressing the issues and the complex context in which the project operates. Sustaining efforts beyond the restoration project until the ecosystem is fully restored prompts many proponents of peatland restoration to establish social capital within their project. To understand and facilitate the establishment of social capital, the Center for Disaster Studies, University of Riau (PSB UNRI), contributed to participatory action research (PAR) led by the Center for International Forestry Research (CIFOR). PAR supports social transformation and behavioral changes in a participatory manner. It helps to foster knowledge exchange and create impact on the ground (Selener 1997; Purnomo et al. 2018, 2020). The project was conducted in Dompas Village of Bengkalis Regency, Riau Province.

Social capital can help to drive collective action within the community to achieve a shared goals or vision (Putnam, 1993; Ido, 2019). Higher levels of social capital are related to higher levels of collective action (Auer et al., 2020). Establishing social capital and collective action is critical in peatland restoration that requires voluntary participation and contributions because the needed resources and costs cannot all be internalized by the project or government budget. However, social capital is complex and difficult to measure; thus, the assessment of social capital varies according to different perspectives and the indicators used (Gomez-Limon et al., 2014). Few studies have considered social capital in the Global South, especially in the context of ecological restoration. Our study aims to fill these gaps by providing empirical evidence on the social capital of women farmers groups in a PAR process. The groups represent those most affected by climate change (Wagey, 2018), but their role, participation, and contribution in land management and environmental conservation has been underrepresented and underappreciated. Herawati et al. (2019) indicated that peatland management is dominated by men, but women have a role in physical activities and decision-making in land management. In the PAR process, two women farmer groups collectively managed 3.3 ha of pineapple agroforestry to support peatland restoration and to provide livelihood and wellbeing improvements. The women were also involved in managing home-garden agroforestry. The groups consisted of women who were primarily housewives, farmers, or agricultural laborers. Despite of their lack of experience and representation in land management, the groups were able to outperform the male farmer groups. With the assumption that social capital may have contributed to their success, we seek to identify what components of social capital this group has, what influences the establishment of social capital, and the extent to which the social capital contributed to collective action within this group.

\section{Theory and Methods}

\subsection{Theory}

The social capital concept used to identify unique characteristics that contributed to the groups' success in managing their action arena and participating in peatland restoration efforts. Social capital components, referred to by Putnam in Field (2016), that build and help the group to function effectively can facilitate coordinated action. Social capital incorporates factors that strengthen social relations. The components used to assess social capital include involvement in the network, reciprocity, trust, social norms, values, and proactive action (Supono, 2011). Different components, such as networks, norms, and trust, according to Putnam (1993), help the community to work together toward a shared goals and orientations.

Various studies through the lens of social capital have shown how a society with a shared vision can build cooperation. They emphasize the importance of social interaction among individuals, among individuals and the group, and among groups, in building a network to achieve the collective desire. As a social entity, human-established cooperation with other actors and institutions through social bound in the intersociety and social bridge of inter society member, which then creating wide network link (Arianto \& Fitriana, 2013). Indonesian communities are tight knit and bound to the culture and traditions of society. They value cooperation as a means of improving their quality of 
life. These dimension of culture and values, as well as social networks, were included in the assessment.

We also seek to understand the reciprocity, trust, and norms that build the social capital. Reciprocity relates to the provision and equivalent repayment of resources from one individual or group to another. A high level of 'reciprocal relationships' are evident in a cooperative and wellfunctioning community. This is shown as a high level of social capital (Baum \& Ziersch 2003). Molm (2010) argued that "reciprocity is both a defining feature of social exchange and a source of societal cooperation and solidarity". Trust comes from the relation on both sides and it's ephiphenomenal (Fukuyama, 2000). In social capital, trust plays a critical part in sustaining the group itself and maintain it as an asset. Strong trust is important in encouraging a positive influence on the environment, especially in village development cases (Prayitno et al., 2019). Thus, maintaining trust also means strengthening the institution and sustaining the transactions and social interactions that occur within (Coleman, 1988). Norms on what is acceptable guide the decisions of the group. They are an important foundation for building and maintaining trust (Lyon 2000). They also regulate interaction within the group.

\subsection{Methods}

\subsubsection{Research site}

We carried out participatory action research (PAR), led by CIFOR, at Dompas Village, Riau Province, from August 2018 to December 2019 (Figure 1). The village land area is largely peat, mostly in degraded condition. Land use in Dompas is categorized as non-forest zone and forest zone (i.e., production and convertible production forest). The non-forest zone (Area Penggunaan Lain, APL) of Dompas Village is utilized for a large-scale commercial oil palm plantation. The forest zone is utilized for pulpwood plantation. The convertible forest zone is utilized by the local community for various agricultural crops. The population of Dompas Village was 1,292 people, $48 \%$ being women. The majority of the community is dependent on the agricultural sector, particularly agricultural crops and plantations, such as rubber, palm oil and coconut (BPS-Statistics of Bengkalis Regency, 2019).

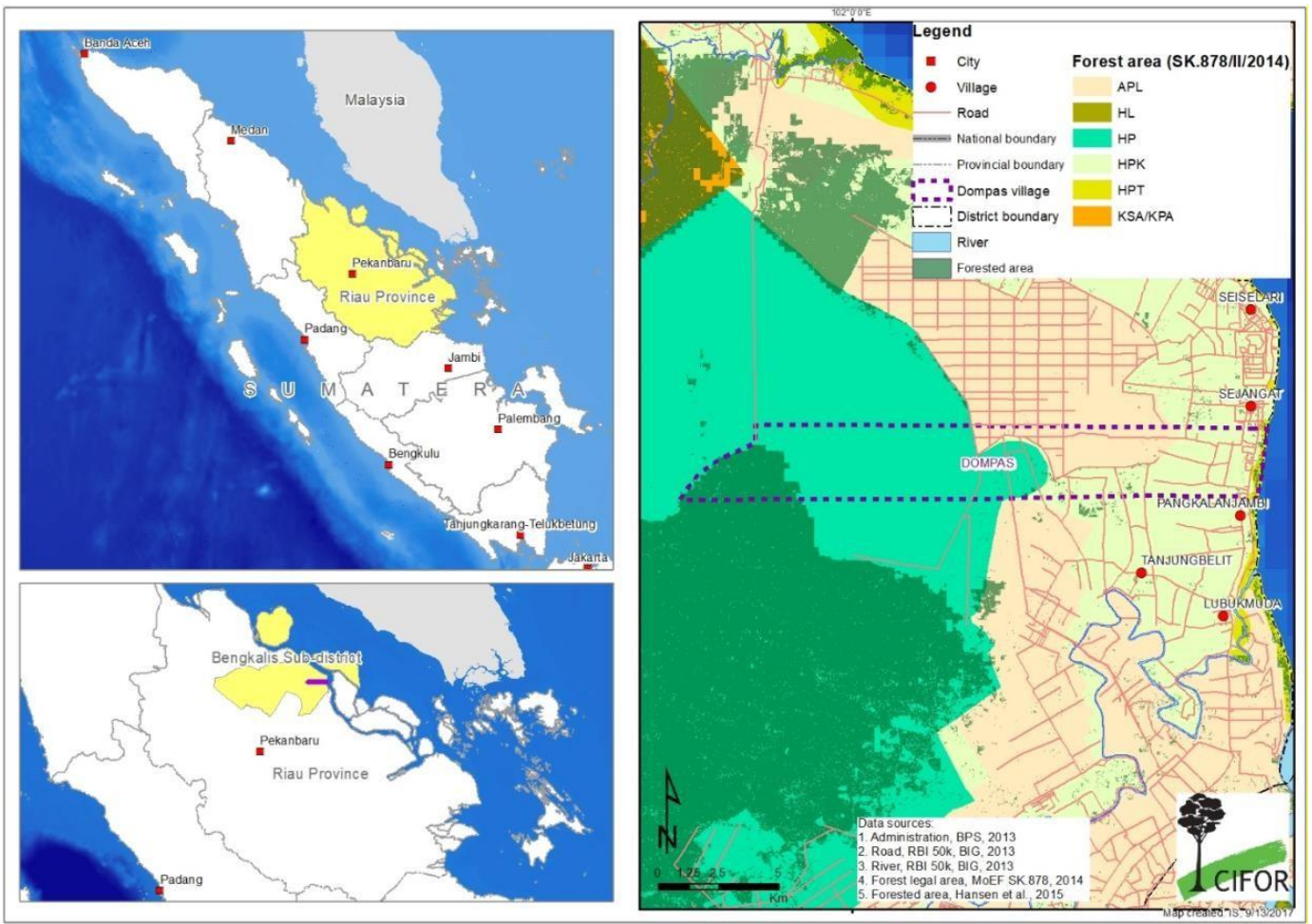

Figure 1. Participatory action research on community-based fire prevention and peatland restoration in Dompas Village 


\subsubsection{Data collection and analysis}

The PAR process comprised loops of phases used to systematically study the peatland restoration and fire prevention in a participatory manner. This also helped the researcher to foster knowledge exchange within the community on sustainable use of peatland and ways to carry out land preparation without using fire. We used a combination of methods. In the reflection phase, we carried out a baseline study through a household survey of 150 respondents and key informant interviews. In the action phase and planning phase, we carried out participant observation and key informant interviews. Finally, in the monitoring phase, we carried out participant observation to monitor behavioral changes in accordance with the theory of change detailed in Figure 2, key informant interviews, and household surveys (end of the project) of 110 respondents. We purposively sampled two women groups, Delima Cemerlang and Melati Cahaya, who collectively manage 3.3 ha of pineapple agroforestry developed under the PAR. We interviewed 17 key informants from these groups. We used interview guidelines containing questions on social capital components, i.e., culture and value, trust, reciprocity, norms, and the social network of the group. We also observed the collective identity within the group and between the group and the community, the level of member participation and proactivity in group and among the group and other groups/community. Data analysis was conducted in a descriptive qualitative manner by triangulating the findings from observations, interviews, and surveys. We analyzed findings that related to the components of social capital, namely the dimensions of value and culture, trust, reciprocity, norms, and social networks. The results of this study were then used to inform empirical evidence on how social and cultural capital has developed and to identify what strategies are needed to strengthen it.

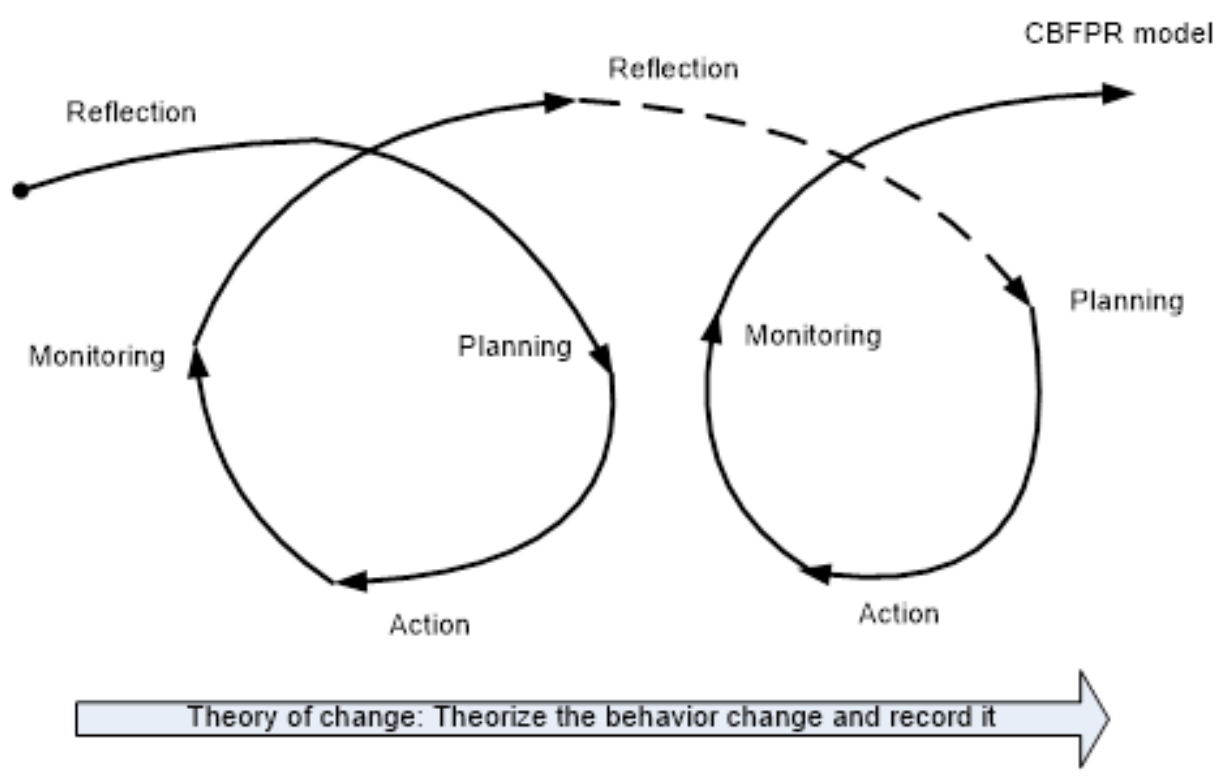

Figure 2. Participatory action research process

\section{Results}

\subsection{The dimension of value and culture}

Social interaction played important part of the social capital and formed through various ways, including through the establishment of a group. Collective values developed and shaped intergroup relationships and, together with norms, value became fundamental for individuals in the group. For the women group, the values, norm, and culture were driven by the genuine intention to contribute to their household by providing an additional income source to improve household wellbeing and welfare. Their intention and their motivation combined to break the perception and stereotypes of women's roles in land management. They outperformed the men farmer group, who managed the others PAR's action arena. This was achieved by maintaining close coordination and communication, 
scheduling routine activities and meetings, dividing roles and responsibilities, and conducting bookkeeping and administration.

Values are formed through traditions and culture that build individual behavior in a group. Social capital will appear spontaneously in the group to regulate personal and group interests (Fukuyama, 2000). Values and norms were strong elements of social capital in both groups of women farmers in making rules that are used to carry out activities and achieve group goals. For example, the groups had flexible working hours because the members were working women and housewives. Hence, the working hours usually started after domestic duties had been completed. Even though the women farmer groups only worked for a few hours, they were consistent with their schedule and worked efficiently and responsibly. This contributed to the significant progress of the action arena they managed.

\subsection{Trust}

Trust functions to reduce or minimize the harm that may arise from group activities. Cooperation will not be possible if it is not based on mutual trust among the parties involved. Further, trust can increase tolerance for uncertainty (Damsar, 2009). Trust in this study was observed in groups and toward external parties.

Women usually only played a small part in land management. Generally, land management, especially on a large scale, was led and carried out by men. A lack of experience did not discourage the women farmer groups from taking the lead in land management. The trust between members of different women farmer groups developed easily as they lived close to each other in the village. As shown in the group leader election, groups can quickly identify and appoint their leaders by choosing those with the traits of ideal leader, such as being hard working and inspirational, and being able to coordinate the members and represent the group in public. During the implementation of the action plan, it was evident that members are trusted to carry out their duties responsibly. The trust towards the outsiders, i.e., CIFOR and PSB UNRI, as facilitators was stimulated through intensive discussion and interaction. The facilitator promoted a healthy discussion that encouraged the community to express their ideas and opinions, as well as giving science- and evidence-based advice to the community. Trust was then shown by acceptance of the facilitator and idea.

"Everyone in this neighborhood have already understood each other character. So, it is a common thing to believe in each other ... Moreover, not all of them can perform in front of the public to be interviewed, only certain people. So, we believe they [the leader] are able to lead the group forward because we have seen how the people [leader] are, [they are] working hard and motivating [us the members]." (Key informant interview, 2019)

Group leaders play a critical role in building mutual trust among the group members. The leader understood the character of each member and provided encouragement. The leaders motivated the community to present their work in public and to meet and discuss with outsiders. The leaders also instilled positive values for members to be open to the facilitators in discussing challenges and the implementation of the activity plan in their village. This, in turn, created enthusiasm and strength, so that the two female farmer groups were empowered and able to implement the action plan better than other, predominantly male, groups in Dompas Village. CIFOR and UNRI, as the facilitators, fostered and shaped the groups' knowledge with science-based information in a participatory manner. The farmer groups, also referred to as co-researchers, initially did not believe in their ability to manage and restore the 3.3 ha of peatland. Their perception was that peatland was difficult to cultivate, especially when the use of fire in land preparation was prohibited by the regulation.

"At the beginning, we were not sure and didn't believe that we were able to do [the peatland management and restoration], because most of them [the farmers] manage the land by using fire [or 'memerun' in local terms] for easier and less labor intensive [land preparation] ... I've never thought to process the [manage and restore] land like this [peatland] because I have only managed small-scale land." (Key informant interview, 2019) 
A community-based peatland restoration monitoring system (CO-PROMISE), developed by CIFOR, showed that the women farmer groups planted at least 29,558 pineapples by the end of the research, in addition to a number of hardwood trees (Okarda et al., 2020). In late 2019, they harvested the crops (Figure 3) and assigned a leader and treasurer to manage the earnings. For checks and balances, they have a bookkeeping and administration system in place, which was used to document the input and output of the production. This system was perceived to be essential to prevent conflict and strengthen trust.

"We sold a total of 2.000 pineapples and they were bought for 2 million [or equal to USS 143 , in total by the intermediary trader]. The money was managed collectively by the leader and treasurer." (Key informant interview, 2019)

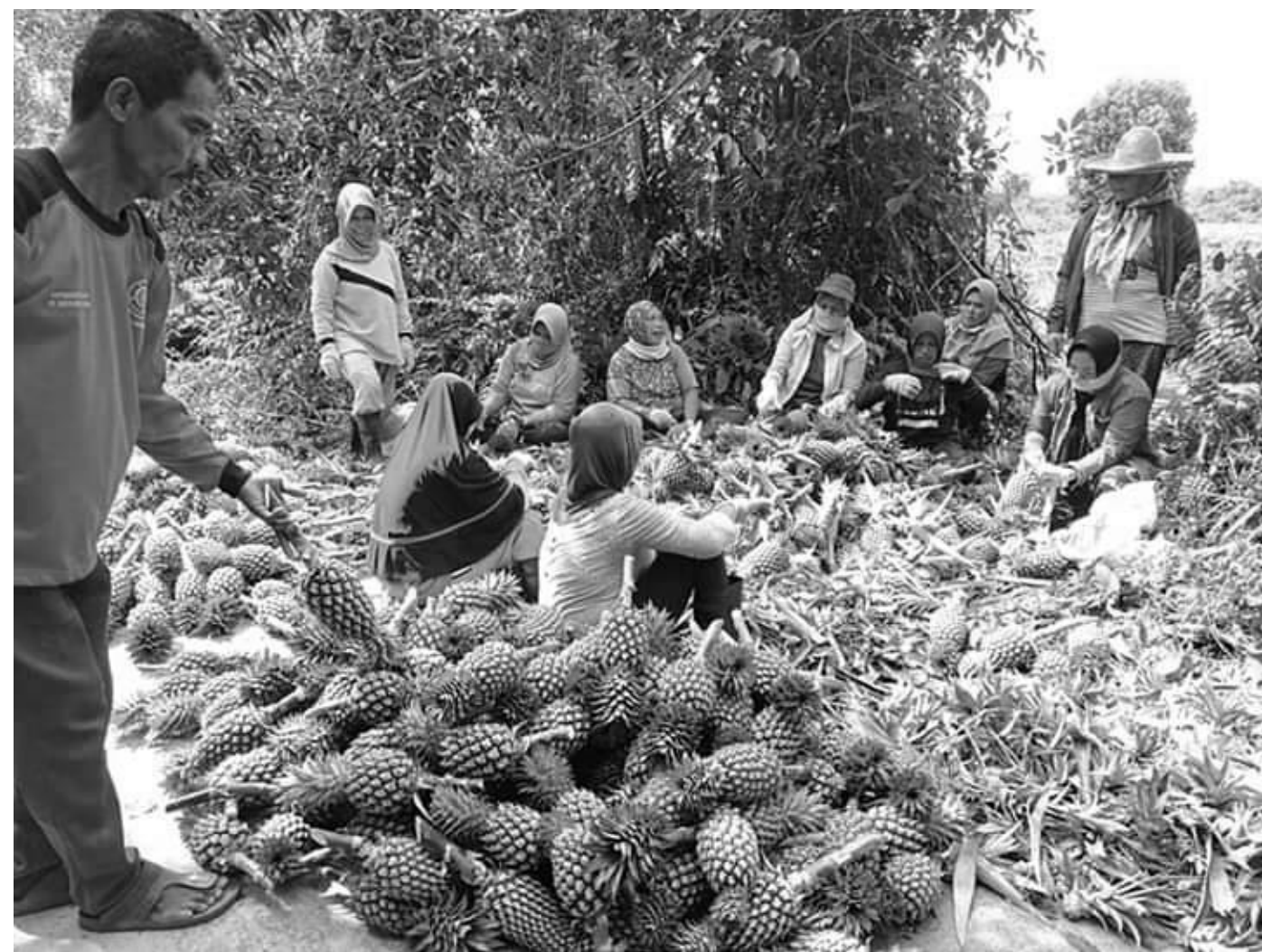

Figure 3. The women farmer groups collectively harvested the pineapple and managed the marketing

\subsection{Reciprocity}

Intergroup members and groups showed reciprocity. This was intangible and often unrecognized, but it was critical capital to sustain the group. In Dompas Village, most of the community, including the women in farmer groups, live below the poverty line. Here, reciprocity in terms of acts of kindness grew naturally. In addition, as participants in PAR, a more practical example of reciprocity was the allocation of profit and the social fund to members who were in need. The system embraced fairness among members by making a schedule and recording the attendance of farmers working to manage and restore the land to proportionally share the profit from harvesting the crops according to members' contributions. Bookkeeping was used to manage the financial capital.

"We also shared [the profit] equally among the member so they can use for fulfilling for the needs of their household when the situation is difficult." (Key informant interview, 2019)

\subsection{Norms}

Norms regulated, guided, and directed the interaction and collective action of the group to achieve its shared goals. The women farmer groups were united by an oral norm. This, combined with the check on balance, mainly covered administrational aspects. Intermember trust meant 
members could carry out their obligations with limited supervision. In addition, their trust in the leader's instruction meant they were willing to adhere to the coordination and schedule that had been set. Members were allocated up to 15 hours a week for managing the action arena, usually after finishing their primary job and domestic work. Every evening, two members of the group patrolled the garden to monitor for wild boar (pest) that destroyed their crops. They also routinely gathered and discussed various issues faced by the group. Their sense of responsibility grew in accordance with the strong foundation of shared goals, vision, and missions. When they could not attend a meeting or participate in planting crops or patrol, they contributed other time to compensate for their absence. Sometimes, they invited their family members to temporarily substitute for them and cover their tasks. They resolved any challenges and problem, both technical and institutional, through forum and consensus. They did not set formal, written regulations nor did they have sanctions. Driven by the strong foundation of shared values and collective action, the members were self-regulated.

"There is no [written or formal] rule or sanction, everything works based on the consciousness. We shared the same responsibility by taking turns in keeping the garden, for example, fertilizing the soil We do [routine] patrols in pairs by turns every day. When someone can't go, those compensate [for the absent days]." (Key informant interview, 2019)

\subsection{Social network of the group}

The dynamic infrastructure of social capital is represented by the social network of the group (Putnam, 1993). This network facilitated communication and interaction, which then enable trust to grow, strengthening the partnership. Before joining PAR, the social network of the women farmer groups was mostly limited to the village and its satellite area. Work as farmer, laborer, or housewife did not provide vast networking opportunities. Most of the members maintain close social networking within their family and neighborhood communities. In the PAR, CIFOR-PSB UNRI encouraged them to actively participate in community-based fire prevention and peatland restoration. This gave the groups the confidence, optimism, capacity, and opportunity to trial the idea and business model, experience the work and interact with a wider network. At the local level, the groups closely networked with other community-based groups who managed other PAR action arenas. Often, they collaborated and contributed to representing PAR by sharing lessons learnt in managing and restoring the peatland at various local to international events. Their work has been acknowledged and recognized by stakeholders and has inspired other community-based groups to learn and develop the action to restore peatland and prevent fire. They expect to utilize the social network for gaining knowledge to improve the value added of their crops and reach a wider market in the future.

\section{Discussion}

In Dompas, women's involvement was limited to specific activities, such as preparation of seedling, planting, or supporting soil fertilization, and they were often excluded from important discussion and decision-making. This led to a lack of experience and limited opportunity to further improve their knowledge and capacity. It psychologically affected them, making them feel discouraged and pessimistic. Our study presents on-the-ground evidence that the inclusion of women capitalized on human resources potential by maximizing the contribution of whole community. The women farmer groups in Dompas showed consensus within the group. They practiced land preparation without using fire in accordance with the fire-ban program and regulation, with the genuine intention of preventing recurring fire. They employed more sustainable practices to support restoration. Their abundant harvest was an added bonus, pointing toward bigger success: reducing the occurrence of fire while improving the productivity of abandoned, degraded peatland. Their adoption of best practices, described above, reconciled ecological needs in land management with the needs to improve the community's wellbeing through sustainable livelihoods (Kusbiantoroa et al., 2016). 
Our study found that the Dompas women farmer group has a high degree of social capital. Social capital is defined as the ability of people to associate with one another and thus become an important force in the economy and other aspects of social existence (Burt, 1992). It is also a relationship that occurs and is bound by trust, mutual understanding, and shared values. This enables group members to engage in collective action efficiently and effectively, according to Prusak L in Field (2016). In Dompas, this was characterized by norms of trust and reciprocity that generate mutually beneficial outcomes. The social capital also led to a high degree of collective action, shown by active participation of all parties in one group in accordance with their respective functions. There was a commitment from each individual to be open to one another, to trust one another, and to give authority to everyone to play their role according to their responsibilities. This produced a sense of togetherness, solidarity, and responsibility for progressing to achieve their action plan. The social capital of the women farmers groups was driven by motivation to contribute to improving the family economy, as well as strengthening capacity through assisting in activities. There women farmers shared values, such as the principles of cooperation among group members in running the farm, being hardworking, fostering mutual trust, helping other group members who were in trouble, and determination to improve the quality of the life and family economy.

Social capital in Dompas arose from interactions between individuals in a group. The level of social capital can be seen from both individual and institutional interactions, such as the creation or maintenance of trust between groups or community members. The strong trust and reciprocity, driven by shared culture and values, is supported by kinship. Trust generated a positive influence toward the group, shown by their ability to overcome conflict (Wibisono \& Darwanto, 2016) and support for establishment and maintenance of interrelationships among individuals (Ghatarani et al., 2020). As the trust gets stronger, the risk of failure decreases (Jumirah \& Wahyuni, 2018). The groups show reciprocity within their collective action, represented by sharing the benefits, instead of rent-seeking. They maintained openness or transparency within the group. This was combined with individual contributions and dynamic interaction supporting success in accomplishing the groups goals (Nizar et al., 2016).

Further, the social capital of the Dompas women farmer group is illustrated in Woolcock (2001), which distinguishes three types of social capital, namely: 'Social bounding' characterized by a strong bond (social adhesive) in a group or societal system. Most members of the women farmer group come from the same ethnic group and have kinship with group members. The similarities in values and traditions function as an adhesive in building interactions. Second, 'social bridging' arises from a variety of group characteristics. This can be seen in the involvement of the Dompas women farmer group in associations and networks. The goal is to maximize the potential of human resources (human resources) and natural resources (natural resources). Third, 'social linking' or a social network is a social relationship across several levels of social power and social status in society. Social capital, especially in the networks and relationships of the Dompas women farmer group, is an indicator of the strength of the group. Extensive networks and relationships are important for the group to overcome the issues it faces.

\section{Conclusions}

Social capital within the women farmer groups contributed to the establishment of collective action, which then led to their success in managing and restoring the peatland. This study identified critical components of social capital for two women farmer groups in Dompas Village. These were characterized by the norms of trust and reciprocity driven by shared culture and values, supported by kinship. Hence, the establishment of social capital in the rural community of Dompas Village arose naturally, largely due to the kinship, culture of cooperation, and shared similarities in values and socioeconomic background. Kinship, in particular, shaped the trust among the members of the group, and for the leader and outsiders. Trust is vital to implementing the restoration activities in Dompas. These were guided by the leader motivating and encouraging the group. Reciprocal relationships were also well-developed, even though there was no norm that regulates their respective duties, women were aware of their responsibilities and carried out their roles properly. There were no sanctions on members for not carrying out group responsibilities. However, there 
was an agreement to reward diligent members by compensating them with greater benefits than those for less active members.

Building collective action for sustainable peatland management and restoration efforts requires the components of social capital to be identified and leveraged. Most peatland restoration projects face serious challenges and incur substantial costs. Voluntary contributions from the community, in terms of collective action, will not only help with the cost but also contribute to shifting from unsustainable use of peatland. Most importantly, the diverse ideas and skillsets it contributes are critical to achieving the overall goal of restoration. Using a PAR approach, we enhanced social capital by giving the community roles and responsibility in identifying the problem and formulating and trialing potential solutions. We provided resources and opportunities for the groups to exercise, develop, and strengthen collaborative action with scientifically sound methods and advice. This paper provided empirical evidence on the efficacy of social capital and collective action in the Global South, with a focus on peatland restoration. This highlights the importance that interventions on peatland restoration should give to establishing social capital to mobilize voluntary participation.

Author Contributions: H.P. designed and coordinated the participatory action research; A.J. designed, managed, and coordinated the social research implementation; Y., D.P., S.S., carried out data collection; A.J., Y., and S.S., analyzed the data; A. J., Y., S. S., and D.P. wrote the manuscript; H.P. reviewed and provided input for the manuscript.

Conflicts of Interest: The authors declare no conflict of interest.

Acknowledgments: This study was a part of the participatory action research to Community-Based Fire Prevention and Peatland Restoration (PAR CBFPR) funded by Temasek Foundation and managed by Singapore Cooperation Enterprise; and participatory action research to Community-Level Business Model funded by Asia Pulp and Paper. PAR CBFPR led by the Center for International Forestry Research (CIFOR) in partnership with the Center for Disaster Studies, University of Riau. The author thanks the women farmer group of Dompas Village for their active participation and engagement throughout the study.

\section{References}

Arianto, K., \& Fitriana, E.N. (2013). Modal Sosial dalam Kemandirian Masyarakat di Bidang Kesehatan. Kebijakan \& Administrasi Publik, 17, 37-49. https://doi.org/10.22146/jkap.6853

Auer, A., Von Below, J., Nahuelhual, L., Mastrangelo, M., Gonzalez, A., Gluch, M., Vallejos, M., Staiano, L., Laterra, P., Paruelo, J. (2020). The role of social capital and collective actions in natural capital conservation and management. Environmental Science \& Policy, 107, 168178. https://doi.org/10.1016/j.envsci.2020.02.024

Baum, F.E., \& Ziersch, A.M. (2003). Glossary: social capital. Journal Epidemial Community Health, 57, 320-323. http://dx.doi.org/10.1136/jech.57.5.320

BPS-Statistics of Bengkalis Regency. (2019). Kecamatan Bukit Batu dalam angka 2019. Bengkalis Regency: BPS-Statistics of Bengkalis Regency.

Burt, R.S. (1992). Excerpt from the social structure of competition, in structure holes: The social structure of competition. Cambridge, MA, and London: Harvard University.

Coleman, J.S. (1988). Social capital in the creation of human capital. The American Journal of Sociology, 94, S95-S120. www.jstor.org/stable/2780243

Damsar. (2009). Pengantar Sosiologi Ekonomi. Jakarta: Kencana Prenada Media Group.

Dommain, R., Dittrich, I., Giessen, W., Joosten, H., Rais, D.S., Silvius, M., \& Wibisono, I.T.C. (2016). Ecosystem services, degradation and restoration of peat swamps in the South East Asian tropics. In A. Bonn, T. Allott, M. Evans, H. Joosten, \& R. Stoneman (Eds.), Peatland restoration and ecosystem services. Cambridge: Cambridge University Press.

Field, J. (2016). Modal Sosial Terj. Nurhadi Cet. 4. Yogyakarta: Kreasi Wacana.

Field, R.D., van der Werf, G.R., Fanin, T., Fetzer, E.J., Fuller, R., Jethva, H., Levy, R., Livesey, N.J., Luo, M., Torres, O., \& Worden, H.M. (2016). Indonesian fire activity and smoke pollution in 2015 show persistent nonlinear sensitivity to El Nino-induced drought. PNAS, 113, 9204-9209. https://doi.org/10.1073/pnas.1524888113 
Fukuyama, F. (2000). Social capital and civil society. International Monetary Fund Issue, 74(18). http://dx.doi.org/10.5089/9781451849585.001

Ghatarani, A., Sheikhmohammady, M., \& Rostami, M. (2020). The impact of social capital and social interaction on customers' purchase intention, considering knowledge sharing in social commerce context. Journal of Innovation \& Knowledge, 5(3), 190-198. https://doi.org/10.1016/j.jik.2019.08.004

Glauber, A.J., Moyer, S., Adriani, M., \& Gunawan, I. (2016). The cost of fire. Jakarta: The World Bank. Gomez-Limon, J.A., Vera-Toscano, E., \& Garrido-Fernandez, F.E. (2014). Farmers' contribution to agricultural social capital: evidence from Southern Spain. Rural Sociology, 79(3), 380-410. https://doi.org/10.1111/ruso.12034

Government of Indonesia. 2016. First nationally determined contribution Republic of Indonesia. Accessed from: http://ditjenppi.menlhk.go.id/reddplus/images/resources/ndc/First_NDC.pdf

Hansson, A., \& Dargusch, P. (2017). An estimate of the financial cost of peatland restoration in Indonesia. Case Studies in the Environment, 2, 1-8. https://doi.org/10.1525/cse.2017.000695

Herawati, T., Rohadi, D., Rahmat, M., \& Winarno, B. (2019). An exploration of gender equity in household: a case from a peatland-based community in Riau, Indonesia. Biodiversitas, 20, 853-861. https://doi.org/10.13057/biodiv/d200332

Hergoualc'h, K., Hendry, D.T., Murdiyarso, D., \& Verchot, L.V. (2017). Total and heterotrophic soil respiration in a swamp forest and oil palm plantations on peat in Central Kalimantan, Indonesia. Biogeochemistry, 135, 203-220. https://doi.org/10.1007/s10533-017-0363-4

Ido, A. (2019). The effect of social capital on collective action in community forest management in Cambodia. International Journal of the Commons, 13(1), 777-803. http://doi.org/10.18352/ijc.939

Joosten, H., \& Couwenberg, J. (2008). Peatlands and carbon. In F. Parish, A. Sirin, D. Charman, H. Joosten, T. Minayeva, M. Silvius \& L. Stringer (Eds.), Assessment on peatlands, biodiversity and climate change: Main report. Kuala Lumpur and Wageningen: Global Environment Centre and Wetlands International.

Jumirah \& Wahyuni, H. (2018). The effect of social capital on welfare in Indonesia. Indonesian Economy and Business, 33(1), 65-76. https://doi.org/10.22146/jieb.29219

Kusbiantoroa, A., Awang, S.A., Maryudi, A., \& Gunawan, T. (2016). social capital role in solving land degradation in Tulis watershed. Komunitas, 8(2), 250-256. http://dx.doi.org/10.15294/komunitas.v8i2.5438

Lyon, F. (2000). Trust, networks, and norms: the creation of social capital in agricultural economies in Ghana. World Development 28, 663-681. https://doi.org/10.1016/S0305-750X(99)00146-

Molm, L.D. (2010). The structure of reciprocity. Social Psychology Quarterly, 73(2), 119-131. DOI: https://doi.org/10.1177/0190272510369079

Nizar, A., Ali, S.S.S., \& Demmalino, E.D. (2016). Social capital: The historical emergence and its implications to agricultural development program. Scientific \& Technology Research, 5(3), 32-37. http://www.ijstr.org/paper-references.php?ref=IJSTR-0716-14834

Okarda, B., Purnomo, H., Basuki, I., Muchlish, U., Arwida, S., \& Baral, H. (2020). Sistem pemantauan restorasi gambut berbasis masyarakat atau Community-based Peatland Restoration Monitoring System (CO-PROMISE). In H. Purnomo \& D. Puspitaloka (Eds), Pembelajaran Pencegahan Kebakaran dan Restorasi Gambut Berbasis Masyarakat. Bogor: CIFOR.

Prayitno, G., Noor, D.S., \& Hidayat, A.R.T. (2019). Social capital, enterpreneurship and rural develompment. Engineering and Scientific Research, 1(2), 84-88. http://dx.doi.org/10.23960/jesr.v1i2.29

Purnomo, H., Ilham, Q.P., \& Achdiawan, R. (2018). Riset Aksi untuk Perbaikan Tata Kelola dan Nilai Tambah Hutan dan Lingkungan. Bogor: IPB Press.

Purnomo, H., Okarda, B., Shantiko, B., Achdiawan, R., Dermawan, A., Kartodihardjo, H., \& Dewayani, A.A. (2019). Forest and land fires, toxic haze, and local politics in Indonesia. International Forestry Review, 21, 1-15. https://doi.org/10.1505/146554819827906799 
Purnomo, H., Puspitaloka, D., Komarudin, H., Andrianto A., Okarda, B., Basuki, I., Prasetyo, P., Qomar, N., Muhammad, A., Sutikno, S., Jalil, A., Yesi, Gunawan, H., Zulkardi, Merbamas, R., Tarsono, \& Wibowo, L.R. (2020). Teori dan Pelaksanaan Riset Aksi Partisipatif untuk Pencegahan Kebakaran Restorasi Gambut Berbasis Masyarakat. In H. Purnomo \& D. Puspitaloka (Eds), Pembelajaran Pencegahan Kebakaran dan Restorasi Gambut Berbasis Masyarakat. Bogor: CIFOR.

Purnomo, H., Shantiko, B., Sitorus, S., Gunawan, H., Achdiawan, R., Kartodihardjo, H., \& Dewayani, A.A. (2017). Fire economy and actor network of forest and land fires in Indonesia. Forest Policy and Economics, 78, 21-31. http://dx.doi.org/10.1016/j.forpol.2017.01.001

Puspitaloka, D., Kim, Y.S., Purnomo, H., \& Fulé, P.Z. (2020). Defining ecological restoration of peatlands in Central Kalimantan, Indonesia. Restoration Ecology, 28, 435-446. https://doi.org/10.1111/rec.13097

Putnam, R. (1993). Making democracy work: Civic traditions in modern Italy. Princeton: Princeton University Press.

Selener, D. (1997). Participatory action research and social change. Ithaca, New York: Cornell University.

Supono, B. (2011). Peranan Modal Sosial dalam Implementasi Manajemen Bisnis. Ekonomi dan Kewirausahaan, 11, 10-16.

Wagey, T. (2018). Pengarusutamaan Gender dalam Tata Kelola Sumber Daya Alam: Inisiasi Kelompok Perempuan dalam Pengelolaan Lahan Gambut. Jakarta: Indonesia Climate Change Trust Fund Didukung Oleh Kementerian Perencanaan Pembangunan Nasional.

Wibisono, G.M.A., \& Darwanto. (2016). Strategy of strengthening social capital of farmer group in agricultural development. Economic and Policy, 9, 62-81. https://dx.doi.org/10.15294/jejak.v911.7187

Woolcock, M. (2001). The place of social capital in understanding social and economic outcomes. Canadian Journal of Policy Research, 2, 11-17. 